DEMOGRAPHIC RESEARCH

VOLUME 37, ARTICLE 18, PAGES 567-598

PUBLISHED 30 AUGUST 2017

http://www.demographic-research.org/Volumes/Vol37/18/

DOI: 10.4054/DemRes.2017.37.18

Research Article

\title{
Marriage in an immigrant society: \\ Education and the transition to first marriage in Hong Kong
}

Muzhi Zhou

Xiaogang Wu

Guangye He

(C) 2017 Muzhi Zhou, Xiaogang Wu \& Guangye He.

This open-access work is published under the terms of the Creative Commons Attribution NonCommercial License 2.0 Germany, which permits use, reproduction, and distribution in any medium for noncommercial purposes, provided the original author(s) and source are given credit.

See http://creativecommons.org/licenses/by-nc/2.0/de/ 


\section{Contents}

1 Introduction $\quad 568$

2 Gender roles and the economic foundations of union formation 569

3 Immigration and the marriage market in Hong Kong 571

$4 \quad$ Education and marriage in Hong Kong 572

$5 \quad$ Data and variables $\quad 575$

$5.1 \quad$ Data $\quad 575$

5.2 Methods and dependent variables $\quad 576$

5.3 Independent variables $\quad 576$

$\begin{array}{lll}5.4 & \text { Descriptive statistics } & 577\end{array}$

$6 \quad$ Results of multivariate analyses $\quad 581$

$\begin{array}{lll}7 & \text { Discussion and conclusion } & 587\end{array}$

$8 \quad$ Acknowledgments $\quad 589$

$\begin{array}{ll}\text { References } & 590\end{array}$

Appendix 596 


\title{
Marriage in an immigrant society: Education and the transition to first marriage in Hong Kong
}

\author{
Muzhi Zhou ${ }^{1}$ \\ Xiaogang $\mathrm{Wu}^{2}$ \\ Guangye $\mathrm{He}^{3}$
}

\begin{abstract}
BACKGROUND

The prevalence of marriages between locals and immigrants is likely to alter the relationship between education and marriage. However, there has been little empirical research on the implications of a large immigration population for the relationship between education and marriage. Hong Kong provides an ideal setting to investigate this issue.
\end{abstract}

\section{METHODS}

This article examines the role of education in union formation for both men and women across two birth cohorts and the effect of education on marriages with local or immigrant spouses, using data from the 2011 Hong Kong Population Census and the Hong Kong Panel Study of Social Dynamics [HKPSSD].

\section{RESULTS}

In contrast to findings in many other societies, local men's education has little effect on union formation. Further analysis reveals that their education is positively associated with marrying a Hong Kong-born spouse but negatively associated with marrying an immigrant spouse born in mainland China. For local women, education has a negative effect on marrying either local or immigrant spouses, but this effect diminishes over time. These findings suggest an increasing importance of women's economic prospects in union formation in a society like Hong Kong where there is a high cost of living.

\footnotetext{
${ }^{1}$ St Antony's College and Department of Sociology, University of Oxford, UK. E-Mail: muzhi.zhou@sant.ox.ac.uk.

${ }^{2}$ Division of Social Science and Institute for Public Policy, Hong Kong University of Science and Technology, Hong Kong. E-Mail: sowu@ust.hk.

${ }^{3}$ Department of Sociology, Nanjing University, China. E-Mail: hgy.gloria@nju.edu.cn.
} 


\section{CONTRIBUTION}

As the first study analysing the role of education in men and women's marriages, over time and with local or immigrant spouses in Hong Kong, this article shows the growing importance of women's economic prospects in union formation. It also demonstrates that the presence of an enlarged pool of potential partners due to immigration can moderate the commonly assumed positive relationship between men's education and marriage.

\section{Introduction}

Given the connection between education and socioeconomic potential, as well as the importance of economic foundations to a stable partnership, educational attainment is an important consideration in the process of partner selection and matching (Blossfeld 2009; Oppenheimer 1988; Schwartz 2013). Numerous studies have examined whether education or economic resources affect marriage timing and whether the association between education and union formation differs between men and women. Evidence from developed countries has generally lent support to a male breadwinner model, in which men's higher socioeconomic status in terms of education and occupation is associated with a higher likelihood of marriage (Kalmijn 2011). The association between women's economic resources and union formation, however, is less consistent. The effect of women's education is found to either converge with that of men's over time or to be contingent upon societal context, with a more negative effect on the union formation in societies with more traditional gender roles (Cherlin 2010; Kalmijn 2013; Ono 2003). However, these empirical studies assume that both men and women are searching for partners within the same marriage pool.

Hong Kong offers a unique setting for examining the role of education in union formation, as its population consists of a large number of immigrants. In fact, one-third of Hong Kong's population was born in mainland China, mostly in neighbouring Guangdong province, which shares a common language with Hong Kong and has a similar folk culture (Pong et al. 2014). Marriages between Hong Kong-born and mainland China-born residents are common. From 1986 to 2006 the proportion of cross-border marriages went from $20 \%$ to $56 \%$ of all marriages registered in Hong Kong each year (Zhou 2016). In particular, a substantial proportion of these immigrants are women migrating to Hong Kong through marriage (Zhang and Wu 2011; Zhou 2016). Before 1991, marriages between male residents of Hong Kong and female residents of mainland China formed about $95 \%$ of the newly registered cross-border marriages each year, but this number gradually dropped, to about $80 \%$ in 2011 (Census 
and Statistics Department 2012a). Such high levels of cross-border marriages and gender asymmetry among immigrants suggest that men and women in Hong Kong may not be searching for potential partners in the same pool. The association between education and union formation in Hong Kong thus may differ from that in other societal contexts.

In this article, based on data from the 2011 Hong Kong census and the Hong Kong Panel Study of Social Dynamics (HKPSSD), we examine the association between education and union formation for both men and women in Hong Kong. As in other advanced societies, but particularly given the high cost of living and growing income inequality in the city, Hong Kong's young generations have substantially delayed marriage compared to previous generations, and cohabitation remains rare. The median age at marriage increased from 24 years old in 1981 to 29 years old in 2011 for women, and from 27 years old in 1981 to 31 years old in 2011 for men (Census and Statistics Department 2012a). In the context of delayed marriages and a high level of crossborder marriages, we propose the following research questions: What is the relationship between education and marriage for men and women in Hong Kong? Has this relationship changed over time? What is the role of the cross-border marriages in moderating the relationship between education and marriage? By answering these questions we aim to provide novel insights into the dynamics of union formation, partner preferences, and gender differences in an immigrant society. In addition, the phenomenon of the feminization of immigration and the increased number of crossborder marriages are also observed in other economically advanced societies in East Asia, such as Taiwan, Japan, and Korea (Yang and Lu 2010). Our study of Hong Kong may also shed light on the role of cross-border marriages in regulating the relationship between education and marriage prospects in these other societies.

\section{Gender roles and the economic foundations of union formation}

Scholars who study the relationship between economic resources and union formation tend to offer gender-specific predictions and explanations, because the expected roles for women and men in the public and private spheres still differ. In a gender-role specialisation setting with men as the primary breadwinners and women as the primary caregivers, family economic and functionalist theorists argue that the utility or function of marriage is maximised through specialisation and exchange (Becker 1985, 1991; Parsons 1949). Men's economic resources enhance the specialisation model within the family, increase the utility of marriage, boost their desirability in the marriage pool, and promote the creation of new households. Alternatively, from the perspective of economic uncertainty, Oppenheimer (1988) argues that low-status jobs, unemployment, 
and unstable careers hinder men's ability to serve as future husbands and fathers. Empirical studies consistently support the theorized role of men's economic resources in enhancing their chance of getting married. Men with superior economic prospects such as a university degree are more likely to marry (Musick, Brand, and Davis 2012). On the other hand, unemployed or precariously employed men tend to delay marriage or experience difficulties in marrying (Kalmijn 2011; Oppenheimer 2003; Oppenheimer, Kalmijn, and Lim 1997; Piotrowski, Kalleberg, and Rindfuss 2015; Yu and Xie 2015).

Whether women's economic prospects enhance their chance of marriage has been a subject of considerable scholarly debate. On the one hand, because of the high opportunity cost of specialising in homemaking and childrearing for women with high economic potential, the gains from marriage are relatively low, which incentivizes more-educated women to remain single (Becker 1991, 1974). On the other hand, women's economic resources are more attractive in societies where the traditional breadwinner-housewife model is less prevalent. When female labour reflects women's desire to pursue a career rather than a means to fulfil the financial needs of the family, women's educational attainment becomes a strong indicator of their future contribution to their household income and is thus valued in the marriage market (Davis 1984; Oppenheimer 1997). Hence, in a situation where there is an increasing cost of living and financial uncertainty and where the traditional specialisation model no longer dominates, yet with improved gender equality in the labour market, economic resources are expected to enhance women's chances of marrying.

Empirical findings on the association between women's economic resources and marriage are inconsistent, which can be attributed to the dramatic changes in women's education and employment status in recent decades. Many studies show little effect of women's employment on their marriage timing (Kalmijn 2007; Liefbroer and Corijn 1999; Xie et al. 2003). In the United States the effect of women's education and/or earnings on marriage has evolved from negative to positive (Cherlin 2010; Sweeney 2002; Sweeney and Cancian 2004). A negative relationship between education and union formation is more likely attributable to the difficulty of starting a household while enrolled in education than to the reduced desirability of marriage due to increased educational levels (Blossfeld and Huinink 1991; Thornton, Axinn, and Xie 2008; Thornton and Young-DeMarco 2001). In summary, empirical studies in Europe and the United States reveal a convergence in the roles of women's and men's socioeconomic attributes in union formation.

However, many studies have consistently reported that education has a negative effect on women's likelihood of marrying in Italy, Japan, and South Korea, where traditional gender roles are relatively strong (Choe 2006; Kalmijn 2013; Ongaro 2001; Ono 2003; Raymo 2003; Raymo and Iwasawa 2005). There has been far less research 
on education and marriage in Hong Kong. The only study we are aware of is based on interviews with 1,024 women between 1996 and 1997, which reported that moreeducated Hong Kong women tended to marry later (Wong 2005). However, this study does not account for the role of men's education in union formation or the changing effects of education over time, given the substantial societal changes in Hong Kong over the past four decades.

\section{Immigration and the marriage market in Hong Kong}

Hong Kong has a large immigrant population from mainland China. Most immigrants are Cantonese-speaking Han Chinese from neighbouring Guangdong province. As such, more than $90 \%$ of the Hong Kong population is ethnic Chinese (Pong et al. 2014; Zhang and $\mathrm{Wu}$ 2011). These immigration patterns create a relatively high degree of affinity between Hong Kong and mainland China compared to other immigrant societies, and accordingly cross-border marriages are common (Pong et al. 2014; Zhou 2016). As with other international marriages, which are dominated by males in wealthier societies marrying females from less developed societies (Jones and Gubhaju 2009), most cross-border marriages have paired grooms living in Hong Kong with brides from mainland China (So 2003; Zhang and Wu 2011; Zhou 2016). Therefore, the large proportion of immigrants has enlarged the pool of potential partners in Hong Kong, especially the pool of potential female partners.

Immigration levels are dependent on immigration policy. Although immigration policy was temporarily tightened from the late 1950 s to the early 1960 s, due to mass emigration during a famine in mainland China (Zhang, Song, and Wu 2017), Hong Kong's immigration policy remained relatively open until the 1980s. For instance, the 'touch-base' policy, implemented from 1974 to 1980, granted Chinese citizens residency as long as they reached the urban area of Hong Kong (Zhang and Wu 2011). Many mainland immigrants, especially men, entered Hong Kong illegally and were able to remain by securing employment. However, immigration policy was tightened in the 1980s, routes to Hong Kong were closed, illegal immigrants were deported, and a daily quota ranging from 75 to 150 was set for mainland Chinese immigrants (Pong et al. 2014). This policy was maintained until the end of British colonial rule. The handover in 1997 led to changes in the daily quota system. The 'one-way permit' system, for instance, accelerated the application process for travel permits and increased the number of mainland residents allowed to enter Hong Kong for family reunion purposes. These qualified residents include the spouses of Hong Kong residents who have either been separated from their spouses for more than ten years or have a child under the age of 14 with a Hong Kong resident (Zhang and Wu 2011). Before 2000, qualified adult 
mainland residents usually had to wait for ten years or more before receiving a one-way permit to reunite with their spouses in Hong Kong, but in recent years this duration has been reduced to about five years (Bacon-Shone, Lam, and Yip 2008). From the early 1980s, China's Open Door Policy has also significantly facilitated social and economic integration between Hong Kong and mainland China, leading to an increase in the number of Hong Kong residents working in mainland China. All these changes have led to a substantial growth in cross-border marriages between Hong Kong residents and mainland Chinese (Lin and Ma 2008; Zhou 2016). Over 760,000 mainlanders settled in Hong Kong between 1997 and 2012, and most of them were female spouses or dependent children of Hong Kong residents (Pong et al. 2014). Thus, the primary path to residency in Hong Kong for mainland Chinese has shifted from work to family reunion, and the majority of adult mainland Chinese immigrants are now women.

\section{Education and marriage in Hong Kong}

Education plays a critical role in union formation, because education is the main determinant of a person's socioeconomic prospects. As a major global trade hub and financial centre since the extensive deindustrialization that began in the 1980s, Hong Kong offers university graduates high-paying employment opportunities in managerial and professional occupations. Also, there is minimal government intervention in Hong Kong's laissez-faire capitalist economy. Taxation is low, and comprehensive unemployment and retirement benefits do not exist. People with limited education are constrained to low-paying and unstable jobs, and income inequality in Hong Kong is significantly higher than in many developed countries (Wu 2009). In 2010 the median hourly wage of employees with a tertiary education was three times that of people with primary education or below (Census and Statistics Department 2011).

Economic circumstances are particularly important for setting up an independent household in Hong Kong, due to the high cost of living. Housing prices in Hong Kong have been similar to other international cities such as London, New York, Vancouver, and Sydney, and are also highly volatile. Using 1999 as a base year, the private retail rental index grew drastically from 70 in 1990 to 173 in 2014, while the retail price index likewise surged from 52 to 521 during the same period (Rating and Valuation Department 2017). The median housing price in 2016 is estimated at 18 times the median household income (Demographia 2017). Moreover, the proportion of government expenditure on housing dropped from $13 \%$ in 1985 to a mere $7 \%$ in 2015 (Hong Kong Housing Authority 1995, 2016). Private permanent housing made up 62\% of flats constructed in 2010, compared to only $38 \%$ in 1985 . The reduced availability of public housing combined with the rapidly rising cost of private housing make it 
extremely difficult for young people to establish an independent household. As a result, union formation has become largely contingent on economic prospects. Therefore, as both specialisation and economic uncertainty models predict, we expect that educational attainment strongly enhances men's likelihood of marrying.

However, the addition of potential partners from mainland China to Hong Kong's marriage market has offered an alternative for those who may face difficulties marrying locally. Due to the socioeconomic gap between Hong Kong and mainland China and the traditional Chinese custom of women marrying up and moving in with their husbands, the prospect of marrying a Hong Kong resident and relocating to Hong Kong is highly appealing to many mainland Chinese women. Hong Kong Chinese men who have been working in mainland China consistently report the impression of their increased attractiveness as male partners in mainland China, where the living cost is much lower than that in Hong Kong, which makes it easier to find younger, prettier, and sometimes even more-educated wives (Ho 2012; Newendorp 2008; So 2003). The shift in Hong Kong's immigration policy from importing labour to family reunion has also incentivised mainland women to gain Hong Kong residency through marriage (So 2003). In addition, a local man marrying an immigrant wife is less pressurised to purchase a house in Hong Kong because of the relatively long time required for mainland wives to reunite with their husbands in Hong Kong. Immigration has therefore expanded the marriage pool and increased the range of options available to Hong Kong men, especially those with less education. One study on marriages registered in Hong Kong found that Hong Kong men married to mainland women tend to be disadvantaged in terms of education and occupation (Lin and Ma 2008). We thus expect that education is not a critical determinant of union formation for men but is correlated with the spouse's immigration status.

For women, educational levels may still be negatively associated with marriage, given the expectation in Chinese custom for women to marry up. Also, as in many other societies, gender roles in China still differ in that women are expected to be the primary caregivers, while men act as the primary providers (Ji et al. 2017; Qian and Sayer 2016). In Hong Kong the employment rate for married women is lower than that for unmarried women, and women's employment activity remains constrained by their child-rearing responsibilities (Tong and Chiu 2017). Therefore, educational attainment and economic prospects may not be as closely associated for women as they are for men. Besides, the substantial improvement in women's education has reduced the pool of men with equal or higher educational attainments for women that are more educated. Since 1998, slightly more women than men have enrolled in post-secondary education (Census and Statistics Department 2012b). Assuming that Hong Kong women, like their Japanese counterparts, strongly prefer marrying men with equal or more favourable economic prospects who will fulfil traditional gender roles in the family, 
highly educated women are limited to a smaller pool of 'marriageable' partners over time and thus are less likely to marry (Raymo and Iwasawa 2005). Moreover, this deficit is unlikely to be compensated for by male immigrants from mainland China due to the socioeconomic gap between Hong Kong and mainland China. As mentioned earlier, cross-border marriages between Hong Kong-born brides and mainland Chineseborn grooms remain rare (Pong et al. 2014).

Furthermore, growing opportunities in high-paying sectors have allowed women to invest in their career development rather than in family lives characterized by traditional gender-role specialisation (Tong and Chiu 2017; Wong 2005). The growth of managerial and professional occupations has particularly drawn women into highearning jobs (Ngo 2011), while a substantial proportion of women remain unmarried in their late 30s. Since 2001 the proportion of females aged 35 to 39 with post-secondary education who have never married has been around 30\% (Yeung 2008), compared to about $7 \%$ for those with primary education or below (Census and Statistics Department 2015). ${ }^{4}$ The negative relationship between women's education and union formation is therefore likely to persist, or even become stronger.

On the other hand, the growing importance of women's economic role may increase the desirability of highly educated women as partners. Firstly, Hong Kong's high cost of living has made it increasingly unfeasible to form a household based on a single breadwinner. Secondly, women's educational attainment increasingly reflects their potential earnings. As mentioned earlier, the transformation of the Hong Kong economy has resulted in many more working opportunities and high-paying jobs for women with a college education. In addition, the hiring of foreign domestic helpers has become widespread since the introduction of the labour importation programme in the early 1980s: the proportion of highly educated mothers of children under age five with foreign domestic helpers grew from $40 \%$ in 1986 to more than $60 \%$ in 2005 (Cortés and Pan 2013). This practice has substantially reduced the opportunity cost of childcare and has enabled women with high earning potential to continue their careers after childbirth (Cortés and Pan 2013). Thus, women's education improves their ability to contribute financially and increases their chances of forming an independent household. The negative relationship between women's education and union formation may weaken over time as a result.

To address the issues above, we first provide an overview of the relationship between education and marriage for men and women. We then determine whether these relationships vary across two birth cohorts. Finally, we examine the role of education in sorting individuals into marriages with local or immigrant spouses, which enables us to

\footnotetext{
${ }^{4}$ Females include those born in mainland China and those migrating to Hong Kong through marriage. As most mainland Chinese female brides are less educated than local women, the proportion of unmarried Hong Kong-born women with a primary education or below should be above $7 \%$.
} 
assess the impact of mainland Chinese immigrants on the relationship between education and marriage.

\section{Data and variables}

\subsection{Data}

The population of interest consists of ethnic Chinese, either born in Hong Kong or having migrated to Hong Kong from mainland China before the marriageable age of 16 . We define this population as 'locals' in this study.

First, we use a 5\% sample of the 2011 Hong Kong Population Census to describe the relationship between education and marriage across birth cohorts. The population census data contains basic demographic information such as age, sex, marital status, birthplace, and duration of residence in Hong Kong. We restrict the sample to ethnic Chinese aged 31 to 60 and match these individuals to their coresiding spouses. Unfortunately, we have to exclude individuals born in mainland China because there is no data on the exact age of migration to Hong Kong for immigrants over 40 years old. The descriptive statistics report the marriage patterns of Hong Kong-born residents in 2011. Because there is no information on marriage years or other life events in the census data, we use the Hong Kong Panel Study of Social Dynamics (HKPSSD) to study the role of education in marriage timing and spouses' immigration status.

The HKPSSD is the first territory-wide population-representative household panel survey in Hong Kong, and 3,214 households and 7,218 adults were successfully interviewed in the first wave in 2011. The data includes sociodemographic information and information on education, marriage, and immigration history ( $\mathrm{Wu} 2016)$. We selected ethnic Chinese aged between 26 and 65, either born in Hong Kong or mainland Chinese who migrated to Hong Kong before the age of 16, and matched the questionnaires of couples currently in coresiding partnerships to identify the birthplace of their spouses. Individuals not currently coresiding with their spouses reported whether their spouses were residents of mainland China. We excluded 30 individuals whose spouses were born in neither Hong Kong nor mainland China and 25 individuals married before age 16. We also used the follow-up surveys conducted during 2013 and 2015 to substitute missing data in the first wave of the HKPSSD.

Our final sample contains 3,213 individuals born between 1946 and 1988. The year of first marriage ranges from 1965 to 2011. 


\subsection{Methods and dependent variables}

We apply discrete-time event history analysis by estimating binary logit models on a person-year file created from the HKPSSD sample. The observational window of each respondent is from age 15 until the year of marriage or the maximum age observed (55) if the individual remained unmarried throughout the observation period. This model is preferred over continuous-time estimation (e.g., Cox proportional hazard model) because the marriage dates are recorded to the nearest year, and all the explanatory variables are measured by years. This discrete-time approach estimates the effects of both time-invariant and time-varying covariates on marriage and accounts for the fact that the dates of marriage are measured discretely with the left censoring problem solved (Allison 2014).

We estimate two sets of models. The dependent variable for the first set of logit models is whether an individual is married in the interval of a year. For the second set of logit models we examine the effects of education on sorting individuals into three competing outcomes: remaining unmarried, marrying a spouse born in Hong Kong, and marrying a spouse born in mainland China. ${ }^{5}$ In this analysis we report two sets of coefficients for each variable. The first set is the effect on the odds of marrying a spouse born in Hong Kong rather than not marrying, and the second set is the effect on the odds of marrying a spouse born in mainland China rather than not marrying. The sample for this analysis is restricted to those who have either never been married or are currently in their first marriage, because only information on the current spouse's birthplace can be matched (93\% of the married individuals are in their first marriage). ${ }^{6}$ The samples are weighted, and the standard errors for clustering of observations within individuals are adjusted.

\subsection{Independent variables}

Education. Two time-varying variables quantify educational levels in a person-year record. These variables are constructed based on a person's educational history and educational level at the time of marriage for the married population. The first variable indicates whether an individual is enrolled in an educational institution in the specific person-year. The second variable indicates educational qualifications that individuals are currently enrolled for or have attained during the specific person-year. The

\footnotetext{
${ }^{5}$ We tried an alternative definition in which immigrant spouses were defined as those who came to Hong Kong after age 16 . The results were almost identical. Therefore, the simpler identification of the spouse type based on their birthplace should suffice.

${ }^{6}$ Although the divorced population is increasing, the proportion of divorced/separated and remarried individuals remains small, increasing from 3\% in 2001 to about 5\% in 2011 (Yip et al. 2014).
} 
educational levels are classified into three categories: 'middle school or below' (reference category), 'high school or equivalent', and 'tertiary education.'

Formal employment. A dummy variable indicating whether the individual currently holds or previously has held a formal job is created based on the year in which the individual was first formally employed. ${ }^{7}$ Its value is zero until the year when the person starts formal employment. This value remains 1 as long as the person has formal employment.

Birth cohort. For the descriptive statistics using the sample from the census data, the birth cohorts are classified into '1950s', '1960s', and '1970s.' For our regression analyses using the sample from the HKPSSD data, we classify individuals into two birth cohorts. They are an older cohort (born between 1946 and 1967) and a younger cohort (born between 1968 and 1988). This is because the majority of individuals born before 1968 married before 1990 in our data, whereas the younger cohort was more likely to have married after 1990. Moreover, several societal changes also occurred shortly before or after 1990, such as a shift in immigration trends from importing labour to family reunion, the expansion of tertiary education, rising income inequality and housing prices, the handover in 1997, and the economic transition from industry to services.

Control variables. Our other variables associated with marriage timing are age, birthplace, and family background (Blossfeld 2009; Blossfeld and Huinink 1991; South 2001). Two time-varying variables, namely the logarithm functions of current age minus 15 and 65 minus current age, are used to construct a bell-shaped model of the effect of age on timing of marriage, as identified in previous studies (Blossfeld 2009; Kalmijn 2011). The first age variable indicates the decline after the peak of the bellshaped curve, while the second indicates the initial rise. Birthplace is a dichotomous variable. A value of 1 indicates that an individual was born in mainland China rather than Hong Kong. Family background, represented by the educational attainment of the more-educated parent, is another time-invariant variable. Parental education is classified in three categories: 'primary school or below' (reference category), 'middle school', and 'high school or higher.'

\subsection{Descriptive statistics}

Based on the census sample, Figure 1 shows the distribution of the population that is currently or has previously been married and the unmarried population, by educational attainment in each birth cohort for men and women born in Hong Kong. The proportion of men who are currently or have previously been married is similar across different

\footnotetext{
${ }^{7}$ We considered including initial occupation in the models but found its effect to be statistically insignificant.
} 
educational groups in the two older cohorts. However, the equivalent proportion of women has been consistently lower for those with higher levels of educational attainment, although this negative educational gradient is less steep for the 1970s cohort. The last three bars in each figure show the proportion of individuals who have married versus those who have never married over time. The proportion of unmarried individuals almost doubled between the two older cohorts, increasing from $10 \%$ to $20 \%$ for men and from $12 \%$ to $21 \%$ for women. Therefore, a significant proportion of the Hong Kong-born population has remained unmarried after the age of 42, which is the age of the youngest members of the 1960s birth cohort.

Figure 2 shows the proportions of marriages with spouses born in Hong Kong versus those with spouses born in mainland China, by educational attainment and birth cohort, for currently married individuals born in Hong Kong. There are, again, significant differences between men and women. The proportion married to mainland Chinese women is higher among less-educated men across all three cohorts. However, this pattern is less evident among women. About $20 \%$ of married Hong Kong men are married to mainland Chinese women. The proportion of Hong Kong women married to mainland Chinese men remains low, particularly among younger women. In the 1950s birth cohort the relatively higher proportion of marriages between Hong Kong-born brides and mainland China-born grooms reflects the mass male migration to Hong Kong before the 1980s (Hua 2006).

Table 1 presents the weighted summary statistics of the HKPSSD sample used for subsequent multivariate analyses. ${ }^{8}$ Unlike the census sample, the HKPSSD sample includes individuals born in mainland China who migrated to Hong Kong before the age of 16 . About $70 \%$ of men and women were married at the time of the last observation, $31.4 \%$ of whom consist of a Hong Kong-born groom and a mainland China-born bride, while $19.4 \%$ consist of Hong Kong-born brides and mainland Chinaborn grooms. A larger proportion of married men in the younger cohort are married to mainland China-born women, whereas the opposite is true for women. The results of educational expansion are evident. The proportion of men with tertiary education tripled between the two cohorts, while this increase is even more substantial among women. About $90 \%$ of men have held formal employment, compared to $85.4 \%$ of women, and the latter percentage is higher for women in the younger cohort. An improvement in parental educational attainment is also observed, with more than $80 \%$ of parents educated to primary level or lower in the older cohort and about $50 \%$ in the younger cohort. $14.3 \%$ of men and $12.3 \%$ of women were born in mainland China and migrated to Hong Kong before the age of 16 .

\footnotetext{
${ }^{8}$ As the unit of analysis is person-year record from the year in which an individual turned 15 until the year of marriage (if before the age of 55) or until the age of 55 if unmarried, the descriptive statistics represent data from the last person-year observation.
} 
Figure 1: Distribution of marital status by education group and birth cohort
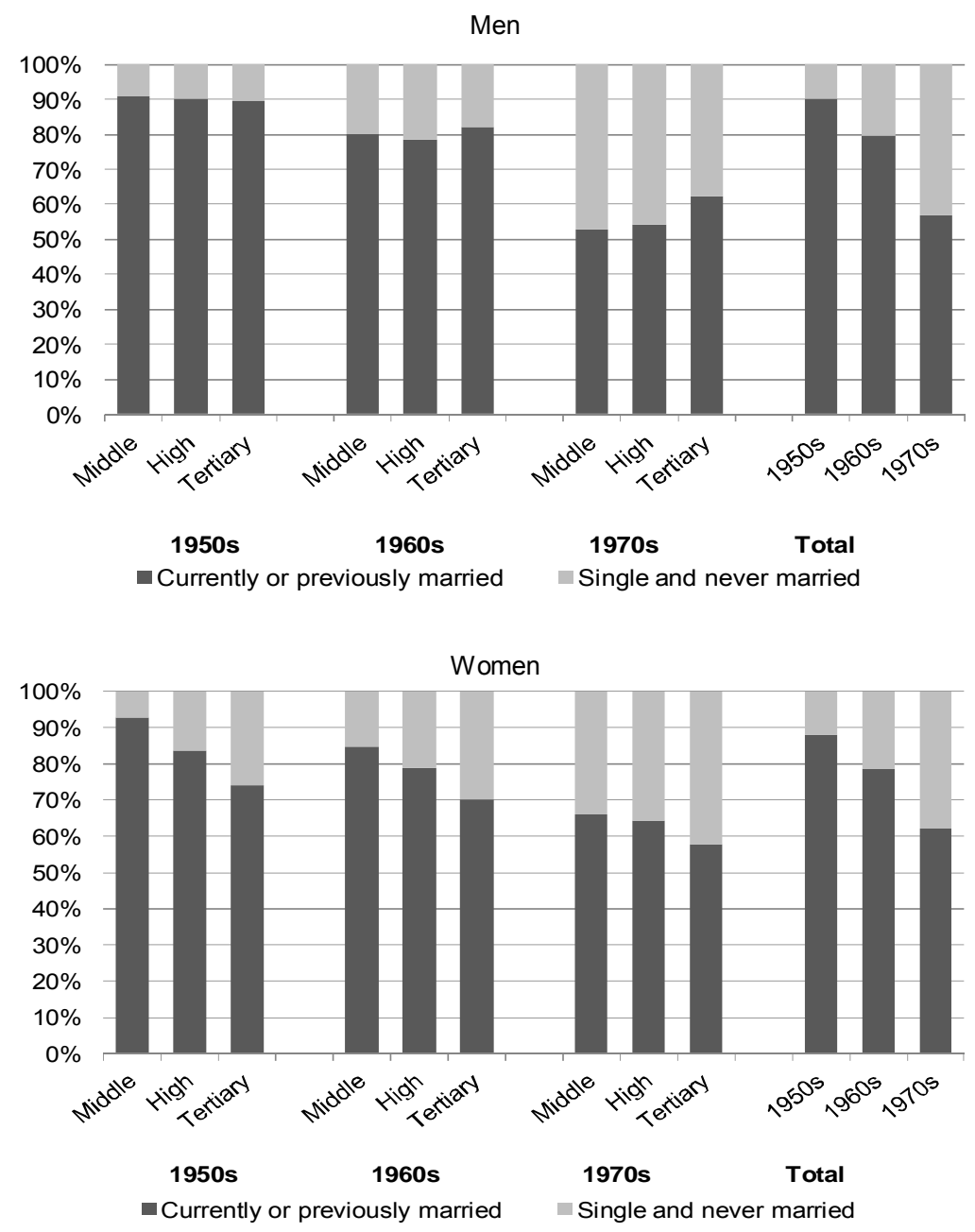

Source: 5\% 2011 Hong Kong Population Census. 
Figure 2: Distribution of marriages with a Hong Kong-born or mainland China-born spouse, by education group and birth cohort
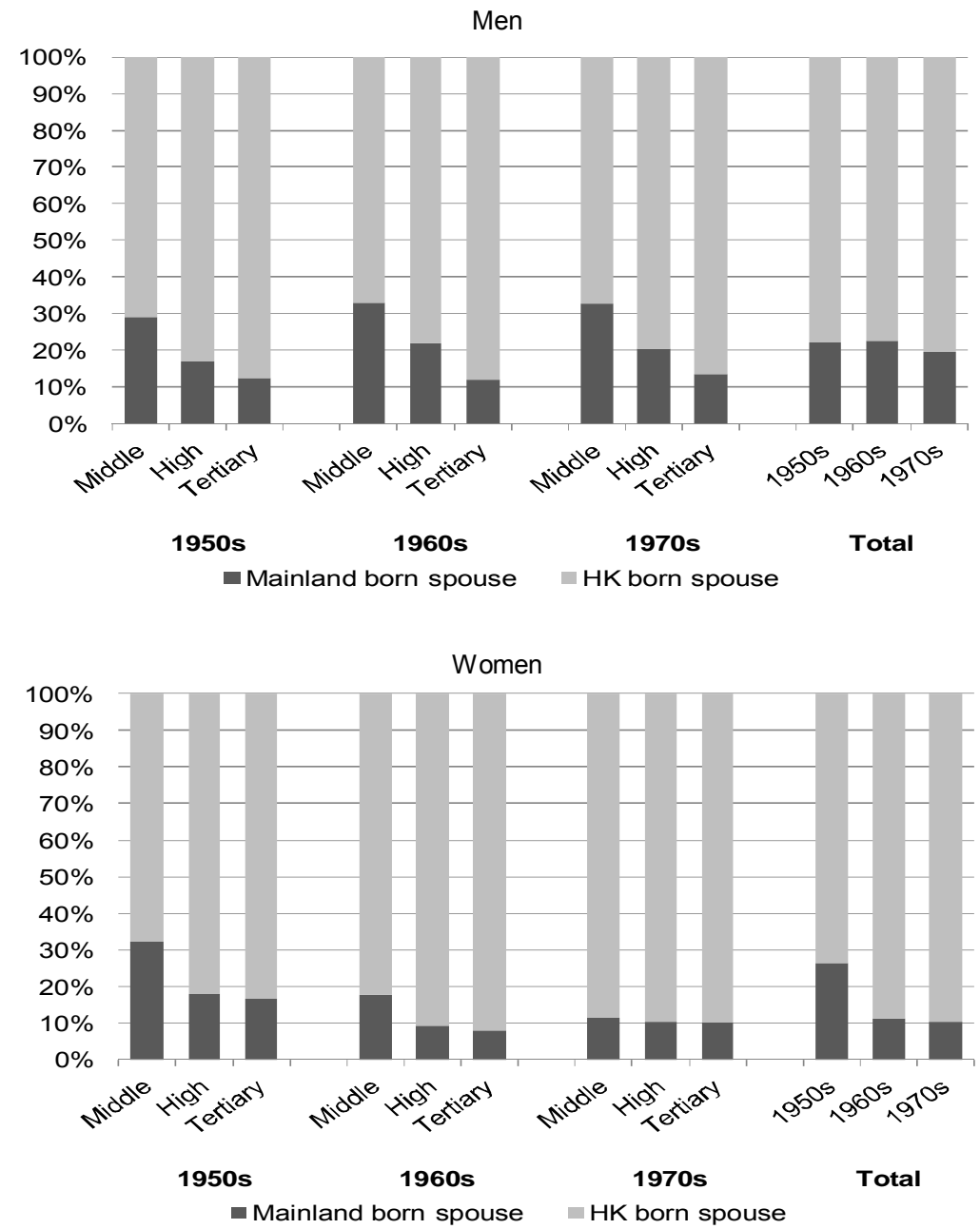

Source: 5\% 2011 Hong Kong Population Census. 
Table 1: Weighted descriptive statistics of selected variables, by men and women

\begin{tabular}{|c|c|c|c|c|c|c|}
\hline & \multicolumn{2}{|c|}{$\operatorname{Men}^{\mathrm{a}}$} & \multicolumn{4}{|c|}{ Women $^{\mathrm{a}}$} \\
\hline & All & $\begin{array}{c}\text { 1947-1967 } \\
\text { Cohort }\end{array}$ & $\begin{array}{c}\text { 1968-1988 } \\
\text { Cohort }\end{array}$ & All & $\begin{array}{c}\text { 1947-1967 } \\
\text { Cohort }\end{array}$ & $\begin{array}{c}\text { 1968-1988 } \\
\text { Cohort }\end{array}$ \\
\hline Currently or previously married (\%) & 70.2 & 87.5 & 53.7 & 72.4 & 87.0 & 57.5 \\
\hline $\begin{array}{l}\text { Married to mainland Chinese spouses } \\
\text { among all couples }(\%)\end{array}$ & 31.4 & 28.9 & 35.5 & 19.7 & 23.6 & 13.8 \\
\hline Age (mean) & 44.8 & 53.8 & 35.0 & 45.1 & 53.6 & 35.0 \\
\hline Mean age at marriage & 29.7 & 29.9 & 29.3 & 26.1 & 25.4 & 27.2 \\
\hline 1968-1988 cohort (\%) & 51.1 & & & 49.5 & & \\
\hline \multicolumn{7}{|l|}{ Education (\%) } \\
\hline Middle school or below & 37.8 & 55.4 & 21.1 & 31.4 & 50.7 & 11.6 \\
\hline High school or equivalent & 37.6 & 33.1 & 42.0 & 46.7 & 41.6 & 51.8 \\
\hline Tertiary or above & 24.6 & 11.5 & 37.0 & 22.0 & 7.7 & 36.6 \\
\hline Has had a formal job (\%) & 89.4 & 83.7 & 94.7 & 85.4 & 79.1 & 91.8 \\
\hline \multicolumn{7}{|l|}{ Parental education (\%) } \\
\hline Primary or less & 65.1 & 82.4 & 48.5 & 67.2 & 83.5 & 50.7 \\
\hline Middle school or equivalent & 16.1 & 9.2 & 22.7 & 15.5 & 7.2 & 24.0 \\
\hline High school or above & 18.9 & 8.5 & 28.9 & 17.3 & 9.4 & 25.4 \\
\hline Born in mainland China (\%) & 14.3 & 12.9 & 15.6 & 12.3 & 11.9 & 12.7 \\
\hline Number of Individuals & 1,617 & 830 & 787 & 1,596 & 836 & 760 \\
\hline
\end{tabular}

Notes: ${ }^{a}$ Selected at the time of the last observation (either the person-year observation at age of marriage or censored at age 55). Source: Hong Kong Panel Study of Social Dynamics (HKPSSD)

\section{Results of multivariate analyses}

Table 2 reports the estimated coefficients from the binary logit models to predict the odds of marriage. The estimated coefficients are reported in three columns, for local men and women aged 26 to 65 . The columns report results from the full sample, from a sample of the older cohort (born between 1946 and 1967), and from a sample of the younger cohort (born between 1968 and 1988). The relatively large estimate for the age term log (65 - current age) suggests that the odds of marriage initially increase rapidly. Estimates from the full sample show that the odds of marrying are lower for people born in the younger cohort. Local men and women born after 1967 are 27\% $\left(1-\mathrm{e}^{-0.316}\right)$ and $37 \%\left(1-\mathrm{e}^{-0.463}\right)$ less likely to marry than those in the older cohort. Individuals enrolled in education have a lower chance of marrying. 
Table 2: Discrete-time logistic regressions predicting odds of marriage for local men and women in Hong Kong

\begin{tabular}{|c|c|c|c|c|c|c|}
\hline \multicolumn{2}{|r|}{ Men } & \multicolumn{5}{|c|}{ Women } \\
\hline & All & $1947-1967$ & $1968-1988$ & All & $1947-1967$ & $1968-1988$ \\
\hline \multirow[t]{2}{*}{ Log (current age-15) } & $3.054^{\star * \star}$ & $2.658^{\star \star *}$ & $3.821^{* \star *}$ & $2.284^{\star \star \star}$ & $2.145^{\star \star \star}$ & $2.817^{\star \star \star}$ \\
\hline & $(0.240)$ & $(0.251)$ & $(0.660)$ & $(0.193)$ & $(0.220)$ & $(0.400)$ \\
\hline \multirow[t]{2}{*}{ Log (65-current age) } & $5.419^{\star \star \star}$ & $4.942^{\star \star \star}$ & $6.108^{\star * *}$ & $7.058^{\star \star \star}$ & $7.340^{\star \star \star}$ & $6.741^{\star \star \star}$ \\
\hline & $(0.524)$ & $(0.543)$ & $(1.644)$ & $(0.597)$ & $(0.731)$ & $(1.219)$ \\
\hline \multirow[t]{2}{*}{ Born after 1967} & $-0.316^{\star * *}$ & & & $-0.463^{\star \star \star}$ & & \\
\hline & $(0.083)$ & & & $(0.085)$ & & \\
\hline \multirow[t]{2}{*}{ Enrolled in education } & $-1.051^{*}$ & $-1.510^{*}$ & -0.349 & $-1.400^{\star * \star}$ & $-0.998^{\star *}$ & $-1.433^{\star \star}$ \\
\hline & $(0.416)$ & $(0.660)$ & $(0.517)$ & $(0.289)$ & $(0.349)$ & $(0.503)$ \\
\hline \multicolumn{7}{|l|}{ Education (ref: middle school) } \\
\hline \multirow[t]{2}{*}{ High school } & 0.085 & 0.157 & -0.116 & $-0.262^{\star *}$ & $-0.277^{\star \star}$ & -0.213 \\
\hline & $(0.089)$ & $(0.105)$ & $(0.155)$ & $(0.090)$ & $(0.100)$ & $(0.192)$ \\
\hline \multirow[t]{2}{*}{ Tertiary } & 0.097 & 0.194 & -0.098 & $-0.454^{\star \star \star}$ & $-0.668^{\star \star}$ & -0.352 \\
\hline & $(0.106)$ & $(0.145)$ & $(0.163)$ & $(0.138)$ & $(0.250)$ & $(0.211)$ \\
\hline \multirow[t]{2}{*}{ Has had a formal job } & $0.530^{* * *}$ & $0.378^{* *}$ & $0.974^{\star * *}$ & $0.323^{* *}$ & $0.281^{*}$ & 0.353 \\
\hline & $(0.106)$ & $(0.121)$ & $(0.226)$ & $(0.101)$ & $(0.119)$ & $(0.191)$ \\
\hline \multicolumn{7}{|c|}{ Parental education (ref: primary or less) } \\
\hline \multirow[t]{2}{*}{ Middle school } & $-0.359^{* *}$ & -0.142 & $-0.586^{\star \star *}$ & -0.100 & -0.088 & -0.147 \\
\hline & $(0.115)$ & $(0.175)$ & $(0.161)$ & $(0.107)$ & $(0.174)$ & $(0.141)$ \\
\hline \multirow[t]{2}{*}{ High school or above } & $-0.324^{* *}$ & -0.208 & $-0.459^{* *}$ & $-0.300^{\star *}$ & 0.017 & $-0.563^{\star \star \star}$ \\
\hline & $(0.112)$ & $(0.182)$ & $(0.148)$ & $(0.115)$ & $(0.173)$ & $(0.155)$ \\
\hline \multirow[t]{2}{*}{ Born in mainland China } & $0.454^{* * *}$ & $0.479^{* *}$ & $0.467^{\star *}$ & $0.435^{\star \star \star}$ & $0.376^{*}$ & $0.486^{* *}$ \\
\hline & $(0.115)$ & $(0.158)$ & $(0.165)$ & $(0.113)$ & $(0.146)$ & $(0.173)$ \\
\hline \multirow[t]{2}{*}{ Constant } & $-30.181^{* * *}$ & $-27.395^{\star \star *}$ & $-35.121^{\star * *}$ & $-33.392^{\star * \star}$ & $-34.086^{\star \star \star}$ & $-33.990^{* * \star}$ \\
\hline & (2.444) & (2.531) & $(7.495)$ & $(2.586)$ & (3.133) & $(5.330)$ \\
\hline Person-year records & 24,883 & 13,673 & 11,210 & 20,228 & 10,329 & 9,899 \\
\hline
\end{tabular}

Notes: Robust standard errors are in parentheses. ${ }^{*} p<.05^{* *} p<.01{ }^{* * *} p<.001$. Source: Hong Kong Panel Study of Social Dynamics (HKPSSD).

Contrary to theories predicting a positive effect of men's education on marriage, the estimates of men's education are not statistically significant $(\mathrm{p}=.341$ and .359 respectively). Nevertheless, employed men are more likely to marry. Across different cohorts, the effect of men's education remains insignificant. The role of education differs strikingly between men and women. The negative overall effect of education on marriage for women is both strong and statistically significant. For women, the odds of marrying are $23 \%\left(1-\mathrm{e}^{-0.262}\right)$ lower with a high school education or equivalent and $36 \%$ $\left(1-\mathrm{e}^{-0.454}\right)$ lower with tertiary education than with an educational level of middle school or below. The estimated coefficients decrease between cohorts, showing a decrease in the negative effect of education. The role of women's education is in fact statistically insignificant in the younger cohort ( $\mathrm{p}=.266$ and .095 respectively). The positive effect 
of formal employment is larger in the young cohort, although it is only marginally statistically significant $(\mathrm{p}=.065)$.

With respect to the control variables, parental education has a negative effect on marriage among younger individuals. Although the effect of family background is not the focus of this study, this finding is unexpected given that parental socioeconomic status is positively correlated with economic prospects and thus with the ability to marry (Musick, Brand, and Davis 2012). However, greater parental resources can also delay marriage by fostering higher career aspirations, providing a high-quality home environment, or creating a family culture of late marriage (Thornton, Axinn, and Teachman 1995; Avery, Goldscheider, and Speare Jr. 1992). With the increased income inequality in Hong Kong, enlarged differences in home environment may explain the strong effect of parental education. Lastly, both women and men born in mainland China have higher odds of marrying.

The above analyses assume that the shape of the underlying hazard curve of marriage is the same across educational groups, meaning that the effect of education is assumed to be constant over a lifespan. Many previous studies have shown the effect of education to vary based on the duration of exposure to the risk of marriage (Blossfeld 2009). To relax this assumption of the constant effect of education over a lifespan, we include interactions between education and the two age-related variables to allow the shape of the hazard curve to vary based on educational level. We report the results for men and women separately in the Appendix (Table A-1 and Table A-2). Most estimates of the interaction terms are statistically significant, indicating that the gradients of the bell-shaped hazard curves differ between educational groups. We graph the predicted survival curves in Figures 3 and 4 based on the estimates of education, age, and their interaction terms. These curves report the predicted cumulative probabilities of men and women who remain unmarried at a given age, using the older cohort sample and the younger cohort sample respectively. ${ }^{9}$ Local men with tertiary education initially delay marriage in both cohorts but catch up with men with lower levels of education very quickly. Eventually, men in the older cohort with an education level of middle school or below are slightly more likely to remain single after the age of 35 . This educational gradient is less evident for men in the younger cohort. Among women, those who are more educated and in the older cohort are more likely to remain unmarried over their lifetime (Figure 4). For the younger cohort, in Figure 4 the predicted survival rates of women from different educational groups reach a similar level at age 35. Figures 3 and 4 show that the shapes of men's and women's survival curves converge over time.

\footnotetext{
${ }^{9}$ The predicted survival rate is calculated based on predicted probabilities of marriage by duration using estimates from the last two columns for men and women in Table A-1 and Table A-2, respectively. Other variables are fixed at the following values: completed formal education, employed, born in Hong Kong, and parents' education level is primary school or below.
} 
Figure 3: Predicted marriage survival curves for local men, by education group
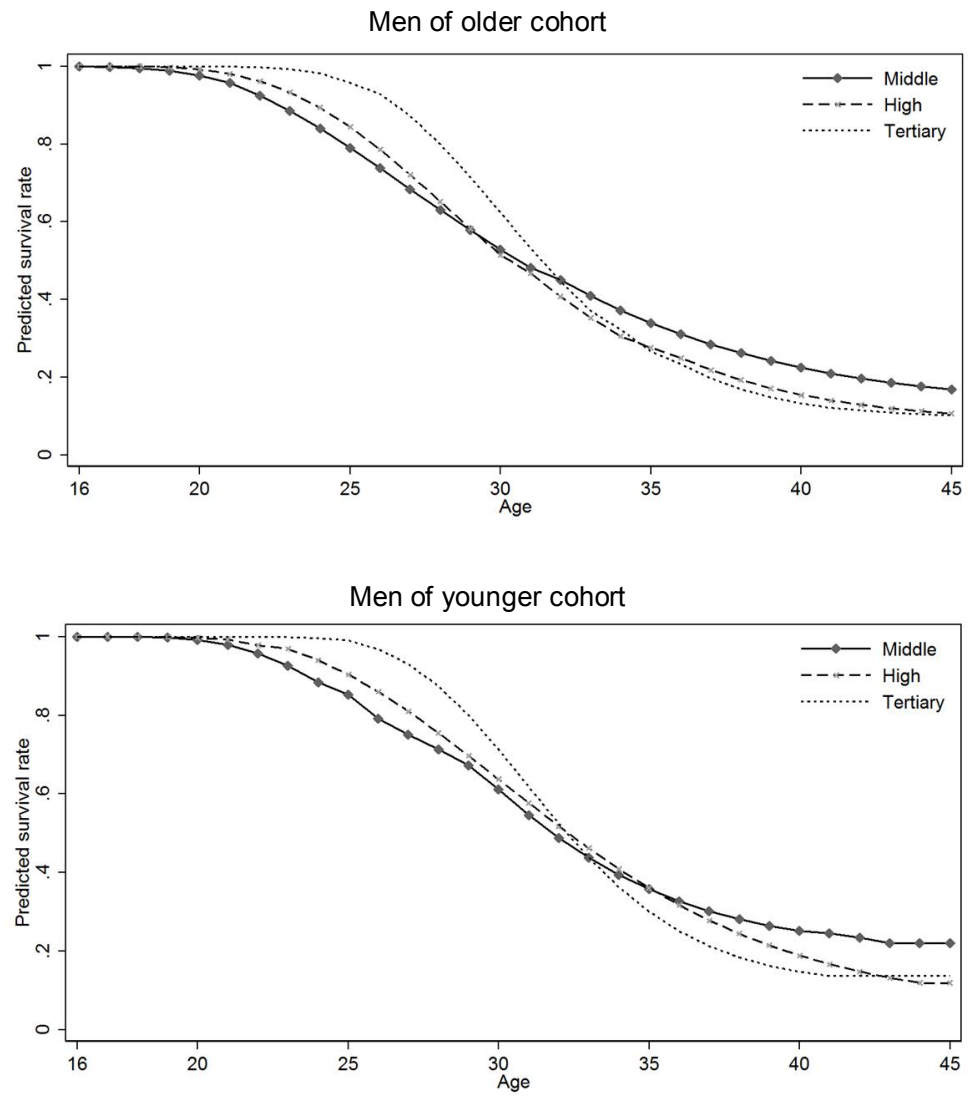

Source: Hong Kong Panel Study of Social Dynamics (HKPSSD). 


\section{Figure 4: Predicted marriage survival curves for local women, by education group}
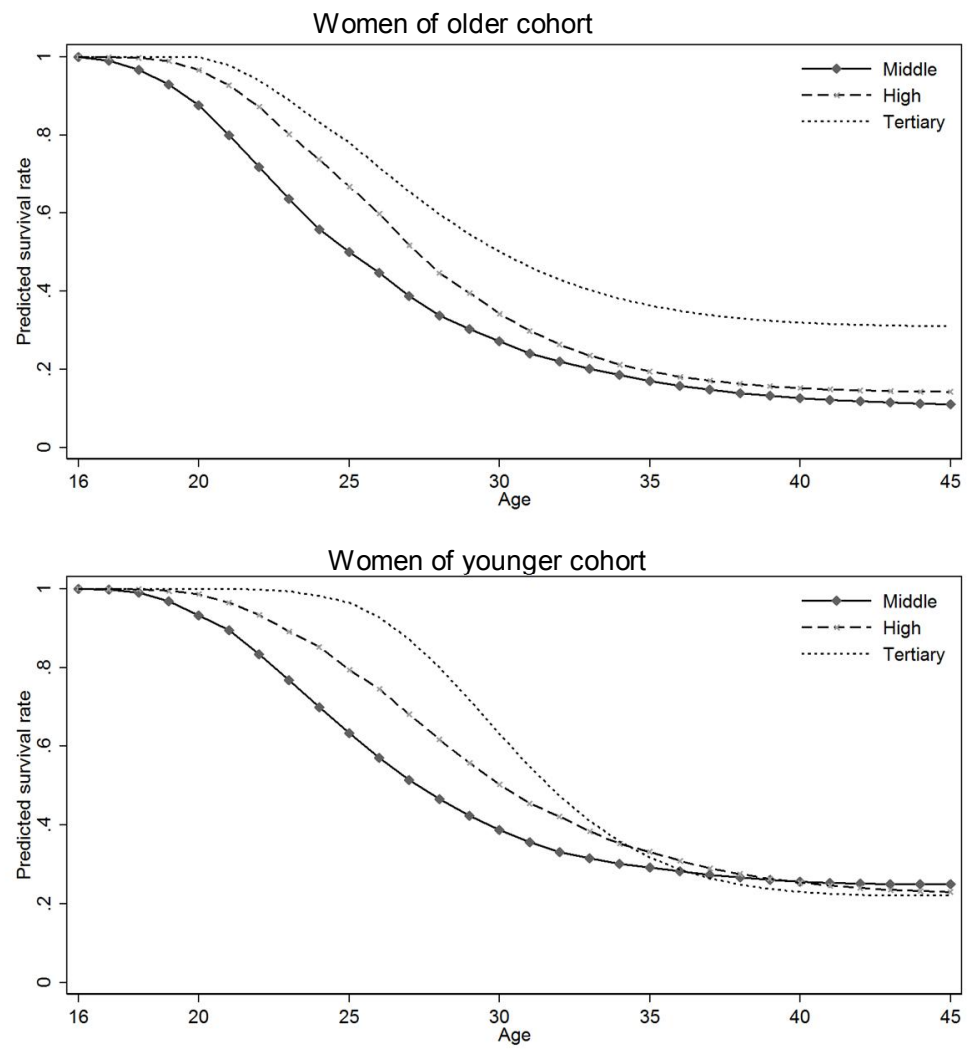

Source: Hong Kong Panel Study of Social Dynamics (HKPSSD).

The pool of potential partners composed of immigrants may moderate the association between education and marriage by sorting individuals into marriages with Hong Kong-born or mainland China-born spouses based on their educational attainment. We employ multinomial logit regression models to evaluate the role of education in sorting individuals into remaining unmarried, marrying a Hong Kong-born spouse, or marrying a mainland China-born spouse, and we report the results in Table $3 .^{10}$

${ }^{10}$ Similar to the regressions performed in Table 2, these analyses based on Table 3 also assume that the effect of education is constant at all ages. We again test this assumption by including interactions between education 
Table 3: Multinomial logistic regressions predicting odds of marrying Hong Kong-born or mainland China-born spouses versus remaining unmarried, for local men and women

\begin{tabular}{|c|c|c|c|c|}
\hline & \multicolumn{2}{|l|}{ Men } & \multicolumn{2}{|l|}{ Women } \\
\hline & HK spouse vs. single & $\begin{array}{l}\text { Mainland spouse vs. } \\
\text { single }\end{array}$ & HK spouse vs. single & $\begin{array}{c}\text { Mainland spouse vs. } \\
\text { single }\end{array}$ \\
\hline \multirow[t]{2}{*}{ Log (current age-15) } & $3.620^{* * *}$ & $2.887^{* \star *}$ & $2.550^{* * *}$ & $2.043^{* * *}$ \\
\hline & $(0.345)$ & $(0.365)$ & $(0.232)$ & $(0.419)$ \\
\hline \multirow[t]{2}{*}{ Log (65-current age) } & $7.570^{\star * *}$ & $3.550^{\star \star *}$ & $7.761^{\star \star *}$ & $7.314^{\star * *}$ \\
\hline & $(0.804)$ & $(0.665)$ & $(0.708)$ & $(1.675)$ \\
\hline \multirow[t]{2}{*}{ Born after 1967} & $-0.523^{* * *}$ & 0.198 & $-0.435^{\star * *}$ & $-0.849^{* * *}$ \\
\hline & $(0.100)$ & $(0.161)$ & $(0.093)$ & $(0.236)$ \\
\hline \multirow[t]{2}{*}{ Enrolled in education } & $-1.105^{\star}$ & -0.517 & $-1.203^{* \star *}$ & $-1.988^{*}$ \\
\hline & $(0.508)$ & $(0.708)$ & $(0.318)$ & $(0.816)$ \\
\hline \multicolumn{5}{|l|}{ Education (ref: middle school) } \\
\hline \multirow[t]{2}{*}{ High school } & $0.245^{*}$ & -0.296 & -0.175 & $-0.650^{* *}$ \\
\hline & $(0.106)$ & $(0.165)$ & $(0.098)$ & $(0.203)$ \\
\hline \multirow[t]{2}{*}{ Tertiary } & $0.341^{\star *}$ & $-0.604^{\star *}$ & $-0.381^{*}$ & $-1.140^{*}$ \\
\hline & $(0.125)$ & $(0.220)$ & $(0.149)$ & $(0.446)$ \\
\hline \multirow[t]{2}{*}{ Has had a formal job } & $0.610^{* * *}$ & 0.172 & $0.357^{\star *}$ & 0.099 \\
\hline & $(0.131)$ & $(0.189)$ & $(0.113)$ & $(0.209)$ \\
\hline \multicolumn{5}{|c|}{ Parental education (ref: primary school) } \\
\hline \multirow[t]{2}{*}{ Middle school } & $-0.390^{* *}$ & -0.406 & -0.154 & 0.232 \\
\hline & $(0.141)$ & $(0.228)$ & $(0.119)$ & $(0.302)$ \\
\hline \multirow[t]{2}{*}{ High school or above } & $-0.435^{\star *}$ & -0.129 & $-0.355^{\star *}$ & 0.096 \\
\hline & $(0.143)$ & $(0.206)$ & $(0.136)$ & $(0.302)$ \\
\hline \multirow[t]{2}{*}{ Born in mainland China } & -0.153 & $1.388^{\star \star *}$ & 0.063 & $1.580^{* * *}$ \\
\hline & $(0.159)$ & $(0.168)$ & $(0.136)$ & $(0.212)$ \\
\hline \multirow[t]{2}{*}{ Constant } & $-39.673^{* * *}$ & $-24.362^{\star \star *}$ & $-36.809^{* \star *}$ & $-35.498^{* * *}$ \\
\hline & $(3.711)$ & $(3.223)$ & $(3.082)$ & $(6.969)$ \\
\hline Person-year records & 23,883 & & 19,603 & \\
\hline
\end{tabular}

Notes: Robust standard errors are in parentheses. ${ }^{*} \mathrm{p}<.05^{* \star} \mathrm{p}<.01^{* \star *} \mathrm{p}<.001$.

Source: Hong Kong Panel Study of Social Dynamics (HKPSSD).

Men's educational attainment is crucial when sorting them into marriages with local or immigrant spouses. Education is positively associated with the odds of marrying a Hong Kong-born woman rather than not marrying and is negatively associated with the odds of marrying a mainland China-born woman rather than not marrying. Specifically, compared to men with an education level of middle school or below, men with tertiary education are $41 \%\left(\mathrm{e}^{0.341}-1\right)$ more likely to marry a Hong Kong-born woman than remain unmarried. By contrast, the most educated men have

and the two age-related variables. The results for marriages with a Hong Kong-born spouse are similar to the full sample analysis reported in the Appendix. The effect of education on the likelihood of marrying a mainland China-born spouse satisfies this assumption because none of the interaction terms is statistically significant. These results are available upon request. 
$45 \%$ lower odds $\left(1-\mathrm{e}^{-0.604}\right)$ of marrying a woman born in mainland China rather than not marrying compared to men with middle school education or below. Therefore, the absence of an overall effect of men's education on marriage reported in Table 2 is a balanced outcome of the counteracting effect of education on matches with local or immigrant women. It is also worth noting that men in the younger cohort are more likely to remain unmarried instead of marrying a Hong Kong-born woman, whereas the odds of marrying a mainland China-born woman rather than remaining unmarried remain unchanged. This indicates that men's delayed marriage is largely due to a delay in marriages between local men and women.

For women, tertiary education is negatively associated with marrying either a Hong Kong-born or a mainland China-born husband versus not marrying. The odds of marrying a Hong Kong-born man or a mainland China-born man rather than not marrying are $32 \%\left(1-\mathrm{e}^{-0.381}\right)$ or $68 \%\left(1-\mathrm{e}^{-1.140}\right)$ lower for women with tertiary education than for those educated to a middle school level or below, respectively. A Wald test of the coefficients reveals that the difference between the estimated coefficients of high school and tertiary education on the two outcomes is only marginally significant $(\mathrm{p}=$ .053). Hence, the role of education in sorting individuals into marriages with spouses of different immigration status is much weaker for women than for men. Furthermore, although both men and women in the younger cohort are less likely to marry Hong Kong-born spouses as opposed to remaining unmarried, only women in the younger cohort are less likely to marry an immigrant spouse than remain single.

\section{Discussion and conclusion}

Theories and past studies on education and union formation are built on the assumption that men and women are searching for partners in the same marriage pool. This article examines the relationship between education and marriage in Hong Kong, where this assumption cannot hold. To the best of our knowledge, this is the first study to examine the impact of men's education on marriage and matching with either Hong Kong-born or mainland China-born spouses. This study also provides the first evidence of the changing effects of education for local men and women over time. Using the most recent data with detailed demographic and socioeconomic information and discrete time event-history analyses, we provide novel findings on the relationship between education and union formation, and offer valuable insights into mating strategies and outcomes in an immigrant society.

Men's education surprisingly has a very limited effect on union formation, despite Hong Kong's high cost of living. After taking into account the ubiquity of marriages formed between local men and immigrant women, we find that men's education has a 
strong, positive effect on marriages with local women but a negative effect on marriages with immigrant women. Therefore, while the relationship between men's education and their likelihood of marrying local women fits the specialisation model, the addition of immigrant women to the marriage pool offers a marriage alternative for local men, and attenuates the disadvantages experienced by less-educated men.

The effect of women's education on entry into marriage remains negative but diminishes over time. Given the significant delaying effects of education for women in the older cohort, women with higher education levels are less likely to marry over an entire lifetime. This finding supports the specialisation model. However, the negative effect of education is weaker for women in the younger cohort, suggesting that the specialisation model is less applicable when the cost of living is increasing and women's economic position is improving. Among women born between 1968 and 1988 , although highly educated women continue to delay marriage in their early 20 s, this effect disappears after the age of 35 . In summary, we observe a convergence of the roles of men's and women's education.

Consistent with a broader global demographic trend that features an increasing mean age at first marriage, the number of marriages in Hong Kong has been declining, primarily due to the decreasing likelihood of unions forming between local men and women and between local women and immigrant men. The relatively stable likelihood of local men marrying immigrant women implies that, compared to local women, local men are more likely to meet mainland Chinese spouses in China and sponsor their immigration to Hong Kong. Therefore, changes in immigration policy have not significantly affected their likelihood of meeting and marrying mainland Chinese women. Due to the traditional custom of hypergamy and patrilocal residence, it remains rare for male mainland Chinese to migrate to Hong Kong through marriage. If earlier marriages between Hong Kong-born brides and mainland Chinese grooms were due to mass male migration to Hong Kong before the 1980s, the substantial reduction in male adult immigrants following the tightening of Hong Kong's immigration policy may explain the reduced likelihood of Hong Kong women marrying immigrant men.

This article is limited in several respects. Although our data includes a detailed educational history, useful for the construction of educational variables prior to marriage, detailed employment history is not currently available in the data. This work thus uses education as the primary indicator of economic prospects. Future studies using specific employment information may provide a more comprehensive understanding of the relationship between socioeconomic status and marriage timing. In addition, our finding that the delaying effects of parental education have strengthened for members of the younger cohort warrants further study, as this finding contradicts the trend documented in other countries (Mooyaart and Liefbroer 2016; South 2001). 
The socioeconomic gap between Hong Kong and mainland China has gradually decreased, due to China's rapid economic growth in the past few decades. Immigration policy continues to change. For example, since 2003 universities in Hong Kong have started to admit students from mainland China, and since 2008 mainland Chinese graduates from these universities can work in Hong Kong. In the same year the Admission Scheme for Mainland Talents and Professionals was implemented to attract highly skilled mainland Chinese to work in Hong Kong (Pong et al. 2014). These changes have likely reduced the social distance between locals and immigrants and have also induced the development of new identities and values (Post, Pong, and $\mathrm{Ou}$ 2014). The dynamic relationship between Hong Kong and mainland China deserves further study in order to enhance our understanding of marital behaviours and preferences and to provide information regarding future social trends.

\section{Acknowledgments}

The authors are grateful for the financial support from the Hong Kong Research Grants Council via the RGC-CPU Strategic Public Policy Research Scheme (HKUST6001SPPR-08) and the General Research Fund (646411) for conducting the first two waves of the Hong Kong Panel Study of Social Dynamics (HKPSSD), implemented by the HKUST Centre for Applied Social and Economic Research (CASER), and grants from the Collaborative Research Fund (C6011-16G) and the Swire Educational Trust for analysis and writing. Guangye He would like to acknowledge the support of National Social Science Fund Project (17CRK024). 


\section{References}

Allison, P.D. (2014). Event history and survival analysis: Regression for longitudinal event data. Thousand Oaks: Sage. doi:10.4135/9781452270029.

Avery, R., Goldscheider, F., and Speare, Jr., A.. (1992). Feathered nest/gilded cage: Parental income and leaving home in the transition to adulthood. Demography 29(3): 375-388. doi:10.2307/2061824.

Bacon-Shone, J., Lam, K.C., and Yip, P. (2008). "One-way permit” system and the Hong Kong population policy. Hong Kong: Bauhinia Foundation Research Centre: 89.

Becker, G.S. (1985). Human capital, effort, and the sexual division of labor. Journal of Labor Economics 3(1, Part 2): 33-58. doi:10.1086/298075.

Becker, G.S. (1991). A treatise on the family. Cambridge: Harvard University Press.

Becker, G.S.(1974). A theory of marriage. Chicago: University of Chicago Press.

Blossfeld, H.-P. (2009). Educational assortative marriage in comparative perspective. Annual Review of Sociology 35: 513-530. doi:10.1146/annurev-soc-070308115913.

Blossfeld, H.-P. and Huinink, J. (1991). Human capital investments or norms of role transition? How women's schooling and career affect the process of family formation. American Journal of Sociology 97(1): 143-168. doi:10.1086/229743.

Census and Statistics Department (2011). 2010 Report on annual earnings and hours survey [electronic resource]. Hong Kong: Wages and Labour Costs Statistics Section (2) and Census and Statistics Department. http://www.statistics.gov.hk/ pub/B10500142016AN16B0100.pdf.

Census and Statistics Department (2012a). Demographic trends in Hong Kong, 19812011 [electronic resource]. Hong Kong: Demographic Statistics Section, Census and Statistics Department. http://www.statistics.gov.hk/pub/B1120017032012X XXXB0100.pdf.

Census and Statistics Department (2012b). Women and men in Hong Kong [electronic resource]. Hong Kong: General Household Survey Section (1) and Census and Statistics Department. http://www.statistics.gov.hk/pub/B11303032012AN12B0 100.pdf. 
Census and Statistics Department (2015). Marriage and divorce trends in Hong Kong, 1991-2013 [electronic resource]. Hong Kong: Demographic Statistics Section, Census and Statistics Department. http://www.statistics.gov.hk/pub/B71501FA2 015XXXXB0100.pdf.

Cherlin, A.J. (2010). The marriage-go-round: The state of marriage and the family in America today. New York: Knopf Doubleday.

Choe, M.K. (2006). Modernization, gender roles, and marriage behavior in South Korea. In: Chang, Y.S. and Lee, S.H. (eds.). Transformations in twentieth century Korea. New York: Routledge: 291-309.

Cortés, P. and Pan, J. (2013). Outsourcing household production: Foreign domestic workers and native labor supply in Hong Kong. Journal of Labor Economics 31(2): 327-371. doi:10.1086/668675.

Davis, K. (1984). Wives and work: The sex role revolution and its consequences. Population and Development Review 10(3): 397-417. doi:10.2307/1973512.

Demographia (2017). 13th annual demographia international housing affordability survey [electronic resource]. Belleville: Wendell Cox Consultancy. http://www.demographia.com/dhi.pdf.

Ho, S.-Y. (2012). Hong Kong men's stories of intra-national cross border romances. Asia Pacific Journal of Social Work and Development 22(3): 176-186. doi:10.1080/02185385.2012.691717.

Hong Kong Housing Authority (1995). Housing in figures [electronic resource]. Hong Kong: City University of Hong Kong and Hong Kong Housing Authority. http://www.cityu.edu.hk/hkhousing/hs/figures/.

Hong Kong Housing Authority (2016). Housing in figures 2016 [electronic resource]. Hong Kong: City University of Hong Kong and Hong Kong Housing Authority. http://www.cityu.edu.hk/hkhousing/hs/figures/.

Hua, T. (2006). Study on marriage squeeze in Hong Kong. [Master Thesis]. Hong Kong: Hong Kong University of Science and Technology, Division of Social Science.

Ji, Y., Wu, X., Sun, S., and He, G. (2017). Unequal care, unequal work: Toward a more comprehensive understanding of gender inequality in post-reform urban China. Sex Roles (electronic first). doi:10.1007/s11199-017-0751-1. 
Jones, G.W. and Gubhaju, B. (2009). Factors influencing changes in mean age at first marriage and proportions never marrying in the low-fertility countries of East and Southeast Asia. Asian Population Studies 5(3): 237-265. doi:10.1080/ 17441730903351487.

Kalmijn, M. (2007). Explaining cross-national differences in marriage, cohabitation, and divorce in Europe, 1990-2000. Population Studies 61(3): 243-263. doi:10.1080/00324720701571806.

Kalmijn, M. (2011). The influence of men's income and employment on marriage and cohabitation: Testing Oppenheimer's theory in Europe. European Journal of Population 27(3): 269-293. doi:10.1007/s10680-011-9238-x.

Kalmijn, M. (2013). The educational gradient in marriage: A comparison of 25 European countries. Demography 50(4): 1499-1520. doi:10.1007/s13524-0130229-X.

Liefbroer, A. and Corijn, M. (1999). Who, what, where, and when? Specifying the impact of educational attainment and labour force participation on family formation. European Journal of Population 15(1): 45-75. doi:10.1023/A:10 06137104191.

Lin, G. and Ma, Z. (2008). Examining cross-border marriages in Hong Kong since its return to China in 1997. Population, Space, and Place 14(5): 407-418. doi:10.10 02/psp.490.

Mooyaart, J.E. and Liefbroer, A.C. (2016). The influence of parental education on timing and type of union formation: Changes over the life course and over time in the Netherlands. Demography 53(4): 1-35. doi:10.1007/s13524-016-0473-y.

Musick, K., Brand, J.E., and Davis, D. (2012). Variation in the relationship between education and marriage: Marriage market mismatch? Journal of Marriage and Family 74(1): 53-69. doi:10.1111/j.1741-3737.2011.00879.x.

Newendorp, N.D.J. (2008). Uneasy reunions: Immigration, citizenship, and family life in post-1997 Hong Kong. Stanford: Stanford University Press.

Ngo, H.-Y. (2011). Trends in occupational sex segregation in Hong Kong. International Journal of Human Resource Management 11(2): 251-263. doi:10.1080/0958519 00339855 .

Ongaro, F. (2001). Transition to adulthood in Italy. In: Corijn, M. and Klijzing, E. (eds.). Transitions to adulthood in Europe. Dordrecht: Springer: 173-208. doi:10.1007/978-94-015-9717-3_8. 
Ono, H. (2003). Women's economic standing, marriage timing, and cross-national contexts of gender. Journal of Marriage and Family 65(2): 275-286. doi:10.1111/j.1741-3737.2003.00275.x.

Oppenheimer, V.K. (1988). A theory of marriage timing. American Journal of Sociology 94(3): 563-591. doi:10.1086/229030.

Oppenheimer, V.K. (1997). Women's employment and the gain to marriage: The specialization and trading model. Annual Review of Sociology 23: 431-453. doi:10.1146/annurev.soc.23.1.431.

Oppenheimer, V.K. (2003). Cohabiting and marriage during young men's careerdevelopment process. Demography 40(1): 127-149. doi:10.1353/dem.2003. 0006 .

Oppenheimer, V.K., Kalmijn, M., and Lim, N. (1997). Men's career development and marriage timing during a period of rising inequality. Demography 34(3): 311330. doi: $10.2307 / 3038286$.

Parsons, T. (1949). The social structure of the family. In: Anshen, R.N. (ed.). The family: Its function and destiny. New York: Harper: 173-201.

Piotrowski, M., Kalleberg, A., and Rindfuss, R.R. (2015). Contingent work rising: Implications for the timing of marriage in Japan. Journal of Marriage and Family 77(5): 1039-1056. doi:10.1111/jomf.12224.

Pong, S.-L., Post, D., Ou, D., and Fok, M.S.Y. (2014). Blurring boundaries? Immigration and exogamous marriages in Hong Kong. Population and Development Review 40(4): 629-652. doi:10.1111/j.1728-4457.2014.00004.x.

Post, D., Pong, S.-L., and Ou, D. (2014). One country two peoples? Asian Population Studies 11(1): 67-93. doi:10.1080/17441730.2014.947699.

Qian, Y. and Sayer, L.C. (2016). Division of labor, gender ideology, and marital satisfaction in East Asia. Journal of Marriage and Family 78(2): 383-400. doi:10.1111/jomf.12274.

Rating and Valuation Department (2017). Property market statistics [electronic resource]. Hong Kong: Government of the Hong Kong SAR. http://www.rvd. gov.hk/en/property_market_statistics/.

Raymo, J.M. (2003). Educational attainment and the transition to first marriage among Japanese women. Demography 40(1): 83-103. doi:10.1353/dem.2003.0008. 
Raymo, J.M. and Iwasawa, M. (2005). Marriage market mismatches in Japan: An alternative view of the relationship between women's education and marriage. American Sociological Review 70(5): 801-822. doi:10.1177/000312240507 000504.

Schwartz, C.R. (2013). Trends and variation in assortative mating: Causes and consequences. Annual Review of Sociology 39: 451-470. doi:10.1146/annurevsoc-071312-145544.

So, A.Y. (2003). Cross-border families in Hong Kong: The role of social class and politics. Critical Asian Studies 35(4): 515-534. doi:10.1080/1467271032000 147014.

South, S.J. (2001). The variable effects of family background on the timing of first marriage: United States, 1969-1993. Social Science Research 30(4): 606-626. doi:10.1006/ssre.2001.0714.

Sweeney, M.M. (2002). Two decades of family change: The shifting economic foundations of marriage. American Sociological Review 67(1): 132-147. doi: $10.2307 / 3088937$.

Sweeney, M.M. and Cancian, M. (2004). The changing importance of white women's economic prospects for assortative mating. Journal of Marriage and Family 66(4): 1015-1028. doi:10.1111/j.0022-2445.2004.00073.x.

Thornton, A., Axinn, W.G., and Teachman, J.D. (1995). The influence of school enrollment and accumulation on cohabitation and marriage in early adulthood. American Sociological Review 60(5): 762-774.

Thornton, A., Axinn, W.G., and Xie, Y. (2008). Marriage and cohabitation. Chicago: University of Chicago Press.

Thornton, A. and Young-DeMarco, L. (2001). Four decades of trends in attitudes toward family issues in the United States: The 1960s through the 1990s. Journal of Marriage and Family 63(4): 1009-1037. doi:10.1111/j.1741-3737.2001.010 09.x.

Tong, Y. and Chiu, S.W.-K. (2017). Women's labor force participation in Hong Kong, 1991-2011. Chinese Sociological Review 49(1): 35-64. doi:10.1080/216205 55.2016.1166045.

Wong, O.M.H. (2005). The socioeconomic determinants of the age at first marriage among women in Hong Kong. Journal of Family and Economic Issues 26(4): 529-550. doi:10.1007/s10834-005-7848-3. 
$\mathrm{Wu}, \mathrm{X}$. (2009). Income inequality and distributive justice: A comparative analysis of mainland China and Hong Kong. The China Quarterly 200: 1033-1052. doi:10.1017/S0305741009990610.

Wu, X. (2016). Hong Kong Panel Study of Social Dynamics (HKPSSD): Research designs and data overview. Chinese Sociological Review 48(2): 162-184. doi:10.13140/RG.2.1.1131.0489.

Xie, Y., Raymo, J.M., Goyette, K., and Thornton, A. (2003). Economic potential and entry into marriage and cohabitation. Demography 40(2): 351-367. doi:10.1353/ dem.2003.0019.

Yang, W.-S. and Lu, M.C.-W. (2010). Asian cross-border marriage migration. Amsterdam: Amsterdam University Press.

Yeung, L.S. (2008). Gender inequality and marriage formation in Hong Kong, 19812006. [Master Thesis]. Hong Kong: Hong Kong University of Science and Technology, Division of Social Science.

Yip, P., Chang, S., Law, F., Tai, L., Tang, S., and Chan, M. (2014). A study on the phenomenon of divorce in Hong Kong. Hong Kong: The University of Hong Kong, Centre for Suicide Research and Prevention.

$\mathrm{Yu}, \mathrm{J}$. and Xie, Y. (2015). Changes in the determinants of marriage entry in post-reform urban China. Demography 52(6): 1869-1892. doi:10.1007/s13524-015-0432-z.

Zhang, Z., Song, S., and Wu, X. (2017). Exodus from hunger: The long-term health consequences of the 1959-1961 Chinese famine. Biodemography and Social Biology 63(2): 148-166. doi:10.1080/19485565.2017.1311203.

Zhang, Z. and $\mathrm{Wu}, \mathrm{X}$. (2011). Social changes, cohort quality, and economic adaptation of Chinese immigrants in Hong Kong, 1991-2006. Asian and Pacific Migration Journal 20(1): 1-29. doi:10.1177/011719681102000101.

Zhou, M. (2016). Educational assortative mating in Hong Kong, 1981-2011. Chinese Sociological Review 48(1): 33-63. doi:10.1080/21620555.2015.1088380. 


\section{Appendix}

\section{Table A-1: Discrete-time logistic regressions predicting marriage for local men with interactions between education and age variables}

\begin{tabular}{|c|c|c|c|}
\hline \multicolumn{4}{|c|}{ Men } \\
\hline & All & $1947-1967$ & 1968-1988 \\
\hline \multirow[t]{2}{*}{ Log (current age-15) } & $2.402^{\star \star \star}$ & $2.148^{\star \star *}$ & $4.136^{\star \star \star}$ \\
\hline & $(0.233)$ & $(0.243)$ & $(0.946)$ \\
\hline \multirow[t]{2}{*}{ Log (65-current age) } & $4.750^{\star \star \star}$ & $4.196^{\star \star \star}$ & $9.255^{\star \star}$ \\
\hline & $(0.579)$ & $(0.575)$ & (2.889) \\
\hline \multirow[t]{2}{*}{ Born after 1967} & $-0.313^{\star \star \star}$ & & \\
\hline & $(0.085)$ & & \\
\hline \multirow[t]{2}{*}{ Enrolled in education } & 0.077 & -0.454 & 0.468 \\
\hline & $(0.404)$ & $(0.621)$ & $(0.554)$ \\
\hline \multicolumn{4}{|l|}{ Education (ref: middle school) } \\
\hline \multirow[t]{2}{*}{ High school } & -9.325 & $-13.838^{*}$ & 21.026 \\
\hline & $(5.489)$ & (6.659) & $(16.188)$ \\
\hline \multirow[t]{2}{*}{ Tertiary } & $-59.493^{\star * *}$ & $-49.361^{* *}$ & -47.917 \\
\hline & $(14.383)$ & $(16.301)$ & $(26.941)$ \\
\hline \multirow[t]{2}{*}{ High school*log (current age-15) } & $1.380^{* *}$ & $1.711^{\star *}$ & -1.007 \\
\hline & $(0.510)$ & $(0.646)$ & $(1.251)$ \\
\hline \multirow[t]{2}{*}{ High school*log (65-current age) } & 1.644 & 2.695 & -5.183 \\
\hline & $(1.192)$ & $(1.425)$ & (3.661) \\
\hline \multirow[t]{2}{*}{ Tertiary*log (current age-15) } & $7.117^{\star \star *}$ & $5.798^{* * *}$ & $6.370^{*}$ \\
\hline & $(1.426)$ & $(1.643)$ & $(2.506)$ \\
\hline \multirow[t]{2}{*}{ Tertiary*log (65-current age) } & $11.458^{\star \star \star}$ & $9.627^{* *}$ & 8.697 \\
\hline & $(3.006)$ & $(3.402)$ & $(5.752)$ \\
\hline \multirow[t]{2}{*}{ Has had a formal job } & $0.461^{* \star *}$ & $0.345^{\star *}$ & $0.856^{\star \star *}$ \\
\hline & $(0.105)$ & $(0.120)$ & $(0.228)$ \\
\hline \multicolumn{4}{|c|}{ Parental education (ref: primary school) } \\
\hline \multirow[t]{2}{*}{ Middle school } & $-0.372^{\star \star}$ & -0.169 & $-0.581^{\star \star *}$ \\
\hline & $(0.120)$ & $(0.182)$ & $(0.163)$ \\
\hline \multirow[t]{2}{*}{ High school or above } & $-0.342^{\star \star}$ & -0.197 & $-0.483^{\star *}$ \\
\hline & $(0.119)$ & $(0.192)$ & $(0.150)$ \\
\hline \multirow[t]{2}{*}{ Born in mainland China } & $0.439^{* \star *}$ & $0.463^{* *}$ & $0.435^{\star \star}$ \\
\hline & $(0.114)$ & $(0.157)$ & $(0.162)$ \\
\hline \multirow[t]{2}{*}{ Constant } & $-26.066^{\star \star *}$ & $-23.413^{* \star *}$ & $-47.091^{* * *}$ \\
\hline & $(2.608)$ & $(2.612)$ & $(12.687)$ \\
\hline Person-year records & 24,883 & 13,673 & 11,210 \\
\hline
\end{tabular}

Notes: Robust standard errors are in parentheses. ${ }^{*} p<.05^{* *} p<.01^{* \star *} p<.001$.

Source: Hong Kong Panel Study of Social Dynamics (HKPSSD). 
Zhou, $W u \& H e$ : Marriage in an immigrant society

Table A-2: Discrete-time logistic regressions predicting marriage for local women with interactions between education and age variables

\begin{tabular}{|c|c|c|c|}
\hline \multicolumn{4}{|c|}{ Women } \\
\hline & All & $1947-1967$ & $1968-1988$ \\
\hline \multirow[t]{2}{*}{ Log (current age-15) } & $1.838^{\star \star \star}$ & $1.728^{\star * *}$ & $2.585^{\star \star \star}$ \\
\hline & $(0.207)$ & $(0.220)$ & $(0.515)$ \\
\hline \multirow[t]{2}{*}{ Log (65-current age) } & $6.691^{\star \star *}$ & $6.314^{* * *}$ & $9.641^{* * *}$ \\
\hline & $(0.844)$ & $(0.865)$ & $(2.648)$ \\
\hline \multirow[t]{2}{*}{ Born after 1967} & $-0.469^{* * *}$ & & \\
\hline & $(0.087)$ & & \\
\hline \multirow[t]{2}{*}{ Enrolled in education } & -0.556 & -0.650 & -0.515 \\
\hline & $(0.294)$ & $(0.356)$ & $(0.514)$ \\
\hline \multicolumn{4}{|l|}{ Education (ref: middle school) } \\
\hline \multirow[t]{2}{*}{ High school } & $-18.511^{\star \star}$ & $-22.454^{\star \star}$ & -0.301 \\
\hline & $(5.718)$ & $(7.363)$ & $(12.497)$ \\
\hline \multirow[t]{2}{*}{ Tertiary } & $-59.086^{* \star *}$ & -24.986 & $-62.930^{*}$ \\
\hline & $(15.034)$ & $(17.955)$ & $(25.166)$ \\
\hline \multirow[t]{2}{*}{ High schoollog (current age-15) } & $1.856^{\star \star \star}$ & $1.962^{\star * *}$ & 0.946 \\
\hline & $(0.382)$ & $(0.509)$ & $(0.677)$ \\
\hline \multirow[t]{2}{*}{ High schoollog (65-current age) } & $3.840^{* *}$ & $4.853^{* *}$ & -0.572 \\
\hline & $(1.344)$ & $(1.718)$ & $(3.036)$ \\
\hline \multirow[t]{2}{*}{ Tertiary ${ }^{\star} \log$ (current age-15) } & $6.273^{\star \star \star}$ & 1.960 & $7.758^{\star * *}$ \\
\hline & $(1.306)$ & $(1.435)$ & $(2.053)$ \\
\hline \multirow[t]{2}{*}{ Tertiary*log (65-current age) } & $11.911^{\star \star \star}$ & 5.409 & $11.953^{*}$ \\
\hline & $(3.288)$ & $(4.050)$ & $(5.607)$ \\
\hline \multirow[t]{2}{*}{ Has had a formal job } & $0.239^{*}$ & 0.226 & 0.283 \\
\hline & $(0.100)$ & $(0.121)$ & $(0.189)$ \\
\hline \multicolumn{4}{|c|}{ Parental education (ref: primary school) } \\
\hline \multirow[t]{2}{*}{ Middle school } & -0.122 & -0.097 & -0.172 \\
\hline & $(0.111)$ & $(0.179)$ & $(0.145)$ \\
\hline \multirow[t]{2}{*}{ High school or above } & $-0.329^{\star \star}$ & 0.007 & $-0.573^{\star * *}$ \\
\hline & $(0.118)$ & $(0.177)$ & $(0.157)$ \\
\hline \multirow[t]{2}{*}{ Born in mainland China } & $0.427^{\star \star \star}$ & $0.366^{\star \star}$ & $0.495^{\star *}$ \\
\hline & $(0.109)$ & $(0.141)$ & $(0.171)$ \\
\hline \multirow[t]{2}{*}{ Constant } & $-31.026^{* \star *}$ & $-29.390^{* * *}$ & $-44.021^{* * *}$ \\
\hline & $(3.506)$ & $(3.612)$ & $(10.749)$ \\
\hline Person-year records & 20,228 & 10,329 & 9,899 \\
\hline
\end{tabular}

Notes: Robust standard errors are in parentheses. ${ }^{*} p<.05^{* *} p<.01^{\star \star *} p<.001$.

Source: Hong Kong Panel Study of Social Dynamics (HKPSSD) 
